\title{
CINEMA AND REALITY: AN INTERVIEW WITH PROFESSOR ERIK KNUDSEN *
}

\author{
Besna AĞIN**
}

Ağın, B. (2020). "Cinema and Reality: An Interview with Professor Erik Knudsen”. Etkileşim. 5. 204209.

We interviewed famous British film researcher and producer Professor Erik Knudsen on cinema and reality. Professor Knudsen is one of the prominent names of the cinema community with his academic studies on cinema, and is known for his experience in filmmaking. Knudsen is known for his works especially in the field of experimental and documentary cinema. We had a conversation with Professor Knudsen, who mastered both the theoretical and practical fields of cinema, on cinema and reality.

-From the beginning, what are the contributions of cinema to humanity?

I don't feel it is cinema that contributes to humanity; people do. And they do so through stories, predominantly, that they tell using various forms. Cinema is one of the forms used by people as they construct their worlds through communication, dialogue and sharing of stories. "The universe is not made of atoms, but stories". (Muriel Rukeyser). Cinema happens to be a new form - joining with other forms such as music, poetry, literature, painting, theatre and even non artistic forms - born specifically out of the industrial age. In this sense, the cinematic form is a new addition to the way people can tell their stories. While cinema may not have changed the underlying stories being told, cinema will have changed the way people tell some of those stories. Cinema has, therefore, in that sense contributed to an expansion of the language we use to articulate our stories. In the first instance a language exclusively controlled by the few, who therefore controlled the stories being told through the medium, to now being a democratised language accessible to all. This democratisation is impacting on how cinematic language is used, for what purpose and is leading to cinema not just being about one way conversations between people, but a medium for multilateral conversations.

* Professor, University of Central Lancashire, School of Journalism, eknudsen@uclan.ac.uk, Orcid: 0000-0001-8361-6975

** Research Assistant, Üsküdar University, Faculty of Communication, besna.agin@uskudar.edu.tr, Orcid: 0000-0002-1591-0352 
-Our problem is and always was reality when it comes to cinema. What kind of a relationship is there between cinema and reality? Do films reflect reality?

Different expressive forms have differing relationships with reality - whatever that is. The fact that something is a form - or a medium, as cinema is - suggests that the reality lies elsewhere than in the tangible form itself. A story is brought to life in its telling, but the story itself has no form and is therefore intangible. For me, the intangible place where stories live is where the reality lies. The physical tangible world is an articulation of that reality and is, in itself, a medium. Perhaps, therefore, we should be asking not whether films reflect reality, but how do films connect us to an intangible reality which has no form? Cinema takes us to this intangible reality by having a relationship with the everchanging tangible world around us. Here semiotics can be a helpful tool for understanding how cinema engages with this tangible world that we like to call reality, to take us into the intangible reality, which I think of as the true reality. Comparing three time based arts - music, theatre and film - we see that each of these art forms has different priorities in which audiences engage through the semiotic space of iconic, indexical and symbolic to the intangible content. If the iconic relationship between the signifier and the signified is one of verisimilitude, the indexical relationship one of association and the symbolic relationship one of an assigned meaning, we start to see that different arts priorities these semiotic relationships differently. In music, for example, the priority is the indexical; abstract sounds, pitch and rhythm stirring up associations that then lead to iconic creations in the mind's eye. The least important relationship is that a particular sound or rhythm has a designated meaning. (Unless, of course, one is dealing with sounds such as a fire alarm, where the designated meaning is symbolic because we have been taught that semiotic relationship.) The fact that a minor chord makes us more sad and a major chord makes us more happy is an example of the power of pure association - the indexical. Theatre, on the other hand, can be created through an artificial space, such as a stage, or even a designated space such as a table top. The priority here is that that space becomes a symbolic space, filled with symbolic staging and performances from which the audience then starts to associate. The least important semiotic sign for theatre is the iconic; in other words, in a stage performance it is not important that the staging or the performance has verisimilitude and looks and sounds like what it is signifying. In fact, in my experience, the more symbolic and the less iconic a stage play is, the more powerful the form seems to become.

In cinema on the other hand, the first relationship audiences have with the form is the iconic relationship. That is, what we see and what we hear has a close verisimilitude relationship between the signifier and the signified. What you see and hear is what it is supposed to look like. From there, we start to associate. The man looks and sounds like a man and the street looks and sounds like the street - that is the iconic relationship between signifier and signified. From there, we then start to associate; a poor man, a rich street, a happy man,

$$
\text { ISSN: 2636-7955 | Yıl } 3 \text { |Sayı } 5 \text { |Nisan } 2020 \text { | ETKíLEŞiM |205 }
$$


a dangerous street and so on. All the elements in the imagery аге carefully put in place to strengthen this relationship of verisimilitude. If I see a small paper Marché tree on an empty stage, my first reaction is to read that symbolically as a tree. However, if I were to see such a paper Marché tree in a film, my first reaction would be to see it as a paper Marché tree. These differences have significant implications for how one may cast a film and theatre performance differently. (It also demonstrates that music and film are more closely associated in terms of how they work than film and theatre.) Of course, at the end of the day, we are talking about priorities, as there is often a mixture of signs at work simultaneously.

So even though verisimilitude is the crucial relationship in cinema between the signifier and the signified, this does not mean that it reflects reality. You may have a fantasy world, a science fiction world, or whatever, and all cinema establishes is that what you see is close to what it is supposed to be. In cinema, therefore, the рарег Marché tree is a paper Marché tree and not a symbol for a real tree. That is fine, if you want your audience to see it as a paper Marché tree, but not so effective if you want your audience to read it as representing a real tree.

But at the end of the day, reality is this intangible place the medium takes you to.

-All the technological advancements we have achieved in filmmaking has not yet ignited the utmost potential. Is it possible that filmmaking is more than what we have thought so far and it will reveal itself even more in the coming years? Do you think filmmaking can help us be more humane?

These are two very different questions. The question of whether cinema can make us more humane is in my view simple. No. Cinema is a machine and a tool. Cinema is agnostic. It is people who have morals and express those morals. Just like water can one minute be used to save someone's life in that it is essential to life, so the next minute that same water can be used to kill someone. One can therefore not talk about whether water is humane or not.

Who knows what will happen in the future. Look at how European painting in the 18th and 19th century became increasingly accomplished and interested in three dimensional verisimilitude, then a 100 years later Picasso was going back to two dimensional art and inventing cubism. Every art form continually transforms itself as it is used differently in different contexts. Personally, I feel that as I look across all art forms across time, simplicity and poverty tend to be a qualities most great artists strive for. My own motto is: simplicity and independence in an age of abundance and complexity. The old Christian Biblical saying that it is more difficult for a camel to go through the eye of a needle than for a rich man to get to the Kingdom of Heaven, tells me that those who are going to achieve the most with the cinematic form - indeed any form must seek poverty and simplicity in order to reach that sacred space where 
they are able to "make visible what only you can make visible" (Robert Bresson). And in terms of what will actually happen in the future; well, who knows.

-Your book, "Finding the Personal Voice in Filmmaking", philosophically examines ways in which independent filmmakers may explore, through practice, the discovery of a personal voice. How do our own experiences determine our style of filmmaking? How do you evaluate your own personal experiences of filmmaking?

These are incredibly big and difficult questions. They say that necessity is the mother of all invention. My style of filmmaking has been born out of that necessity. My character, my context, my circumstances and the particular challenges of making any film conspire to give my work a direction I would not have been able to think my way towards. In that sense, I have learned to trust and obey my intuition, and the style of filmmaking that has emerged is not one of my making. As André Gide said: "art is a collaboration between God and the artist and the more God has to do with it, the better".

I am constantly reflecting on my work and have created a multimedia project involving poetry, film and photography called Doubt. Doubt has been a very important creative force, one that can, if not handled correctly, paralyse, but on the other hand one that can, if harnessed, be utilised to build a confidence that transcends fears of not being accepted or recognised by one's fellow human beings. As I write in one of my personal notebooks: "To hell with them, to hell with them all; this work is a prayer to my God". I see my work and the stories I tell as part of a bigger story; a microcosm of a macrocosm. Like William Blake, I like to try to "see the universe in a grain of sand" and "eternity in an hour".

-From a filmmaker's perspective, what do you think about Hollywood cinema? How does Hollywood cinema have an impact on European cinema?

There is a difference between Hollywood and American Cinema; and it is also hard to define what is European Cinema, particularly in light of the many different cultural traditions, circumstances and contexts. Hollywood is an industrial complex and as such dominates the global film industry. This industry is highly developed and is built on the fact that the US has a significant home market from which to build that industry. The European film industries collapsed with the introduction of sound, but were in the silent era equal in size to Hollywood, not least because they could command large audiences across language frontiers. The European film industries have subsequently become dependent on state intervention and aid, whereas Hollywood - and now Bollywood and Nollywood - are completely self-sufficient. This means that Hollywood, Bollywood and Nollywood are able to respond to and satisfy market demand by producing popular films. The subsidised industries of European cinemas tend not to have to respond to market demand because of their subsidies and the consequence of this is a predominantly elite film communi- 
ties making work that speaks to the themes that preoccupy these elites rather than address what is popularly demanded.

I do not want to make the mistake of many European commentators and film experts by criticising popular audiences or Hollywood. While there may be films that I like or dislike and while I may have my opinions on the relative merits of films being produced, Hollywood is incredibly successful and has, as a consequence, been able, for over a century, to bring a cluster of highly influential films and ideas to cinema. One of the strengths of Hollywood is that it is open to a hinterland of independent US filmmakers and global filmmakers who generation after generation are swallowed up by the Hollywood machine to continually renew it with new ideas and skills. Hollywood is full of European directors and former indie directors. In relation to the European directors, many of them were not able to have sustained careers in their home European cinematic industries or were creatively constrained by a subsidy heavy systems. In Hollywood, the industrial system there has always been interested in new people and new ideas if it seems like it is going to lead to success. They look at the talents around the world and absorb those talents in ways that European cinemas seem incapable of doing. Contemporary European cinema traditions seem more closed, restricted to the nation state, and when it comes to fully funded industrial scale projects, the history of class and elites plays out in the contemporary scene.

-What could you say about today's British cinema? What are the tendencies?

Official British cinema is dominated by a close service led relationship with Hollywood, on the one hand, and the subsidised industry led by a cultural elite, on the other. The service industry aligned with Hollywood is thriving. The skills and specialist facilities are world leading and cinema is a significant industrial sector. When it comes to indigenous, culturally independent work, British cinema struggles and has done for a long time. This is not helped by a strong literагу and theatrical tradition that permeates all levels of the British establishment. Indigenous British cinema tends to have an external market in mind - particularly the US - and therefore ends up producing work that fits in with the stereo typical view of Britain and Britishness. The period drama, the gritty working class drama, the London centric romantic comedy are examples of particular genre that dominate British filmmaking. British audiences do not watch British films and many of the culturally most prominent British filmmakers remain completely unknown to British audiences.

As a consequence, many of the best British writers and directors who want to work beyond the stereotypes end up in the US, either in Hollywood or in the independent sector.

-Regarding the technological advancements, what would you say about film production and distribution processes? What do you think is next for cinema? Do you think it is a matter of survival for movies?

208| ETkileşim |Yıl3|Sayı 5 | Nisan 2020 
"The future of cinematography belongs to a new race of young solitaries who will shoot films by putting their last cent into it and not let themselves be taken in by the material routines of the trade" (Robert Bresson, 1977). It is important to think of cinema differently now that it has become more democratised. As Francis Ford Coppola said: "Film is dead; long live cinema". The traditional way of thinking of a film industry or a cinematic tradition can no longer be sustained in a world where everyone is making films. We now have to think of film like we think of music, literature, photography and poetry and we can see from how those sectors and industries work signs of how the future film industries will work. In the UK, for example, over 230,000 book titles (of all types) are published every year. Only a handful of those authors make a living from just writing and many of them are published by very small companies alongside the multinational publishers. The written word is used for a lot more than just entertaining and is integrated into everyone's lives. We are both producers and consumers simultaneously. 